\title{
EFFICACY AND MECHANISM OF TRADITIONAL CHINESE MEDICINE GEL IN SPORTS-RELATED SOFT TISSUE INJURY
}

\author{
EFICÁCIAEMECANISMO DO TRADICIONAL GEL DAMEDICINA CHINESA EM LESÕES DESPORTIVAS \\ DETECIDOS MOLES
}

Original Article

ARTIGO ORIGINAL

Artículo Original

\author{
EFICACIA Y MECANISMO DEL GEL DE MEDICINA TRADICIONAL CHINA EN LESIONES DEPORTIVAS \\ DETEJIDOSBLANDOS
}

\author{
Li Chen' (1D \\ (Public Health) \\ Meiling Miao² (D) \\ (Basic Medicine) \\ 1. Chongqing Normal University, \\ Chongqing, China. \\ 2. Sichuan University, Chengdu, \\ Sichuan, China.
}

\section{Correspondence:}

Chongqing, China.

fm68722@21cn.com;

ef14854@21cn.com

\begin{abstract}
Soft tissue injury is the most common disease in orthopedics, and it is also the most easily neglected disease in sports. Without timely and effective treatment, it is easy to develop into malignant strain and seriously affect life and sports. In view of this, the aim of this study is to analyze the effect and mechanism of traditional Chinese medicine gel in treating such injuries in the light of the characteristics of sports-related soft tissue injury. The right gastrocnemius muscle injury was simulated in 36 adult male rats. Chinese medicine gel and tincture were used to treat it. The contents of interleukin, alanine aminotransferase, blood urea nitrogen and prostaglandin E2 in the blood of rats under different courses of treatment were analyzed to explore recovery in four rats. The results showed that the levels of interleukin and prostaglandin E2 in the blood of rats treated with drugs were significantly lower than those in the control group $(p<0.05)$, indicating that both drugs have obvious therapeutic effects on soft tissue injury. The content of interleukin in the blood of the Chinese medicine gel group was slightly lower than that of the tincture group, indicating that the Chinese medicine gel could affect the recovery of soft tissue injury by affecting leukocyte interleukin. This result is helpful in the treatment of soft tissue injury in sports and to further improve the therapeutic effect of traditional Chinese medicine gel.
\end{abstract}

Keywords: Soft Tissue Injury; Medicine, Chinese Traditional; x'Sports.

\section{RESUMO}

A lesão dos tecidos moles é a doença mais comum na ortopedia, e é também a doença mais facilmente negligenciada nos esportes. Sem tratamento ágil e eficaz, facilmente evolui para luxações malignas, afetando seriamente a vida e a prática de esportes. Em vista disso, o objetivo deste estudo é analisar o efeito e o mecanismo do gel da medicina tradicional chinesa no tratamento de tais lesões, com base nas características da lesão dos tecidos moles relacionada à prática esportiva. Estimulou-se lesão do músculo gastrocnêmio direito em 36 ratos adultos. O gel e a tintura chinesa foram usados para o tratamento. Foram analisados os conteúdos de interleucina, alanina aminotransferase, ureia sanguínea azoto e prostaglandina E2 no sangue dos ratos sob diferentes tratamentos, de modo a explorar a recuperação de quatro ratos. Os resultados mostraram que os niveis de interleucina e prostaglandina E2 no sangue dos ratos tratados com medicamentos eram significativamente inferiores aos do grupo controle $(p<0.05)$, indicando que ambos os fármacos têm efeitos terapêuticos óbvios sobre lesões dos tecidos moles. O teor de interleucina no sangue do grupo gel chinês medicinal mostrou-se ligeiramente inferior ao do grupo tintura, indicando que o gel medicinal chinês pode afetar a recuperação da lesão nos tecidos moles, afetando o leucócito interleucina. Este resultado é útil para o tratamento de lesões dos tecidos moles relacionadas à prática esportiva e para melhorar ainda mais o efeito terapêutico do gel da medicina chinesa tradicional.

Descritores: Lesões nos tecidos moles; Medicina tradicional chinesa; Efeito terapêutico; Mecanismo de Ação; Esporte.

\section{RESUMEN}

La lesión de los tejidos blandos es la enfermedad más común en la ortopedia, y es también la enfermedad más fácilmente descuidada en los deportes. Sin tratamiento ágil y eficaz, fácilmente evolucionan a luxaciones malignas, afectando seriamente la vida y la práctica de deportes. En vista de eso, el objetivo de este estudio es analizar el efecto y el mecanismo del gel de la medicina tradicional china en el tratamiento de tales lesiones, con base en las características de la lesión de los tejidos blandos relacionada a la práctica deportiva. Se estimuló lesión del músculo gastrocnemio derecho en 36 ratones adultos. El gel y la tintura china fueron usados para el tratamiento. Fueron analizados los contenidos de interleucina, alanina aminotransferasa, urea sanguínea, nitrógeno y prostaglandina E2 en la sangre de los ratones bajo diferentes tratamientos, de modo de explorar la recuperación de cuatro ratones. Los resultados mostraron que los niveles de interleucina y prostaglandina E2 en la sangre de los ratones tratados con medicamentos eran significativamente inferiores a los del grupo control $(p<0.05)$, indicando que ambos fármacos tienen efectos terapéuticos obvios sobre lesiones de los tejidos 
blandos. El tenor de interleucina en la sangre del grupo gel chino medicinal se mostró ligeramente inferior al del grupo tintura, indicando que el gel medicinal chino puede afectar la recuperación de la lesión en los tejidos blandos, afectando el leucocito interleucina. Este resultado es útil para el tratamiento de lesiones de los tejidos blandos relacionadas a la práctica deportiva y para mejorar aún más el efecto terapéutico del gel de la medicina china tradicional.

Descriptores: Lesiones en los tejidos blandos; Medicina tradicional china; Efecto terapéutico; Mecanismo de Acción; Deporte.

\section{INTRODUCTION}

Traditional Chinese medicine has a good reputation in the world. External application of traditional Chinese medicine can reduce the side effects caused by drug metabolism in the body through the liver. The application methods of external traditional Chinese medicine mainly include application, fumigation, external washing, etc., but these traditional methods are cumbersome in process and complex in operation, which is not conducive to the wide promotion and exertion of efficacy. ${ }^{1}$ With the combination and progress of chemical raw material technology and pharmaceutical science, Chinese medicine gel preparation has become a stable and widely used drug dosage form. By purifying the gel matrix of midday purification by chemical technology, the property of Chinese medicine can be completely retained in the gel. During the use, the gel will soften the stratum corneum of the drug part, reduce the resistance of the stratum corneum to the drug entering the body, and greatly improve the penetration efficiency of the medicine. Many sports have strong antagonism, and participants sprain and fall under the action of muscle force and external force.2 Among sports injuries, there are also some minor soft tissue injuries and chronic strain injuries. Such injuries will not cause too much damage to the human body at the initial stage, so it is easy to be ignored and eventually develop into strain, which will seriously affect the competition and training of athletes. ${ }^{3}$ In view of the particularity of athletes' time, it is necessary to treat the soft tissue injury caused by sports quickly and not hinder the normal training. In view of this, this study used rat test to simulate soft tissue injury in sports, and explored the efficacy and mechanism of Chinese medicine gel in treating such diseases.

In this study, we studied the efficacy and mechanism of Chinese medicine gel. First, we introduced the mechanism of Chinese medicine gel in treating soft tissue injury and the cause of soft tissue injury. Then, according to the characteristics of soft tissue injury, animal experiments were designed to establish gastrocnemius muscle injury models in 36 rats. Objective to analyze the levels of interleukin, alanine aminotransferase, blood urea nitrogen and prostaglandin E2 in the blood of rats at different stages of treatment, and observe the tissue sections of right gastrocnemius muscle and kidney organs, so as to obtain the therapeutic effect of the two drugs and their toxicity to individual kidney organs.

The innovation of this study is to compare the recovery of Chinese medicine gel and tincture by animal test. After comparing the two drugs, the recovery of the right gastrocnemius muscle after the treatment of the right gastrocnemius muscle before treatment, after five times and ten times after treatment was analyzed. Due to the particularity of animal experiment, the content of interleukin and prostaglandin E2, which can reflect the immune capacity of rats, was selected as the indicators of soft tissue recovery. Alanine aminotransferase (ALT) and blood urea nitrogen (BUN), which can reflect the function of kidney organs, were selected as indicators to reflect the toxicity of drugs to kidney. The research transforms subjective soft tissue recovery into quantitative indicators, so as to make the test results more accurate and convincing.

\section{RELATED WORKS}

Traditional Chinese medicine (TCM) has a good curative effect and reputation in the world, and it has been paid more and more attention by the academic circles. The use method, mechanism and dosage of traditional Chinese medicine are the topics of concern. Shuiqing Z C's team systematically reviewed the randomized controlled trials of ear acupuncture / auricular point pressure (EAP) under all clinical conditions, and found that there were significant differences in other factors of treatment, such as score, treatment time and frequency, and believed that there was no definite conclusion that the design of EAP was the most appropriate pseudo control. ${ }^{4}$ Seda and other scholars evaluated the impact of back massage on delivery pain and delivery by analyzing the delivery satisfaction of massage during delivery. They found that the score of massage group was $8.8 \pm 0.7$, which was significantly higher than that of control group. They proposed that health professionals can use massage intervention to reduce pain and shorten delivery time. ${ }^{5}$ On the basis of literature reports, Wang $m$ and other scholars introduced the application of metabonomics in the evaluation of curative effect of traditional Chinese medicine and its biochemical mechanism, providing changes in the metabolic network of the system for describing the pathological state of animal models and clinical studies. ${ }^{6}$ In view of the characteristics of traditional Chinese medicine with low toxicity, less adverse reactions and more ingredients, Hua Dong Z's team summarized the development of Chinese medicine in reversing tumor multidrug resistance, and provided a certain direction for the development of appropriate reversal agents to overcome multidrug resistance? Z Zhang $\mathrm{s}$ team explored the effects of traditional Chinese medicine, astragaloside $\mathrm{N}$ and curcumin on tumor growth and angiogenesis in nude mice model of human liver cancer. The results showed that as IV and curcumin alone or in combination could significantly reduce the average tumor weight $(P<0.05)$, and the single use of as IV and curcumin could reduce the tumor microvessel count. ${ }^{8}$

Based on the above studies, most of the academic researches on traditional Chinese medicine are to explore the mechanism of action of traditional Chinese medicine and the influencing factors of recovery of sports injury by means of systematic review and animal experiments. There are few studies on the effect and mechanism of important effects in the treatment of sports injury. This study will explore the effect of external application of traditional Chinese medicine gel on simulated male sports rats with soft tissue injury, aiming at exploring the efficacy of Chinese medicine gel, and providing scientific and reasonable suggestions for athletes.

\section{Effect and mechanism analysis of traditional Chinese medi- cine gel in treating soft tissue injury}

$\mathrm{IL}-1 \beta$ is a cytokine produced by monocytes, fibroblasts or other types of cells in response to infection. It can stimulate the production of colony-stimulating factor, platelet growth factor and other cytokines, and play a role in immune response and tissue repair. PGE2 is an important 
cell growth and regulatory factor with immunosuppressive and anti-inflammatory effects. Therefore, the contents of IL-1 and PGE2 in the blood of rats can reflect the recovery of soft tissue injury. This study analyzed the effect and mechanism of tincture and traditional Chinese medicine gel on the role of IL-1 beta and PGE2 in the blood of rats.

The "**" in Figure 1 indicates that compared with the normal group, $P<0.05$; " 0 " indicates that compared with the control group, $P>0.05$. It can be seen from Figure 4 (a) that after soft tissue injury modeling, the content of $\mathrm{IL}-1 \beta$ in blood of group A was significantly lower than that of other groups, and the difference was significant $(P<0.05)$, which indicated that this study was successful in modeling right gastrocnemius muscle injury in rats. The levels of IL-1 beta in rats treated with tincture and Chinese medicine gel were significantly lower than those in A and $B$ rats, that is, after any drug intervention. This indicates that the two drugs can reduce the level of $\mathrm{IL}-1$ beta in the serum of rats. However, there was no significant difference in the content of $\mathrm{L}-1 \beta$ between the two groups after drug intervention ( $P>0.05$ ). The content of $I L-1 \beta$ in group D was higher than that in group $C$.

Figure 1 (b) shows the content of PGE2 in the blood of rats at 0 , 5 and 10 days of treatment. Similar to the results shown in Figure 4 (a), after 10 times of treatment, the PGE2 content in blood of rats in groups $C$ and $D$ was significantly lower than that in rats without drug intervention $(P<0.05)$, but there was no significant difference between groups $C$ and D ( $P>0.05)$, and group D was higher than group $C$. This indicated that tincture and Chinese medicine gel could reduce the content of PGE2 in serum of rats, but there was no significant difference between the two groups.

Figure 2 is a 400 fold enlarged pathological section of the right gastrocnemius muscle of rats. $X 0, X 5$ and $X 10$ show the situation of rats in group $x$ before treatment and after five and ten treatments respectively. It can be seen from the figure that fiber breakage and edema can be clearly
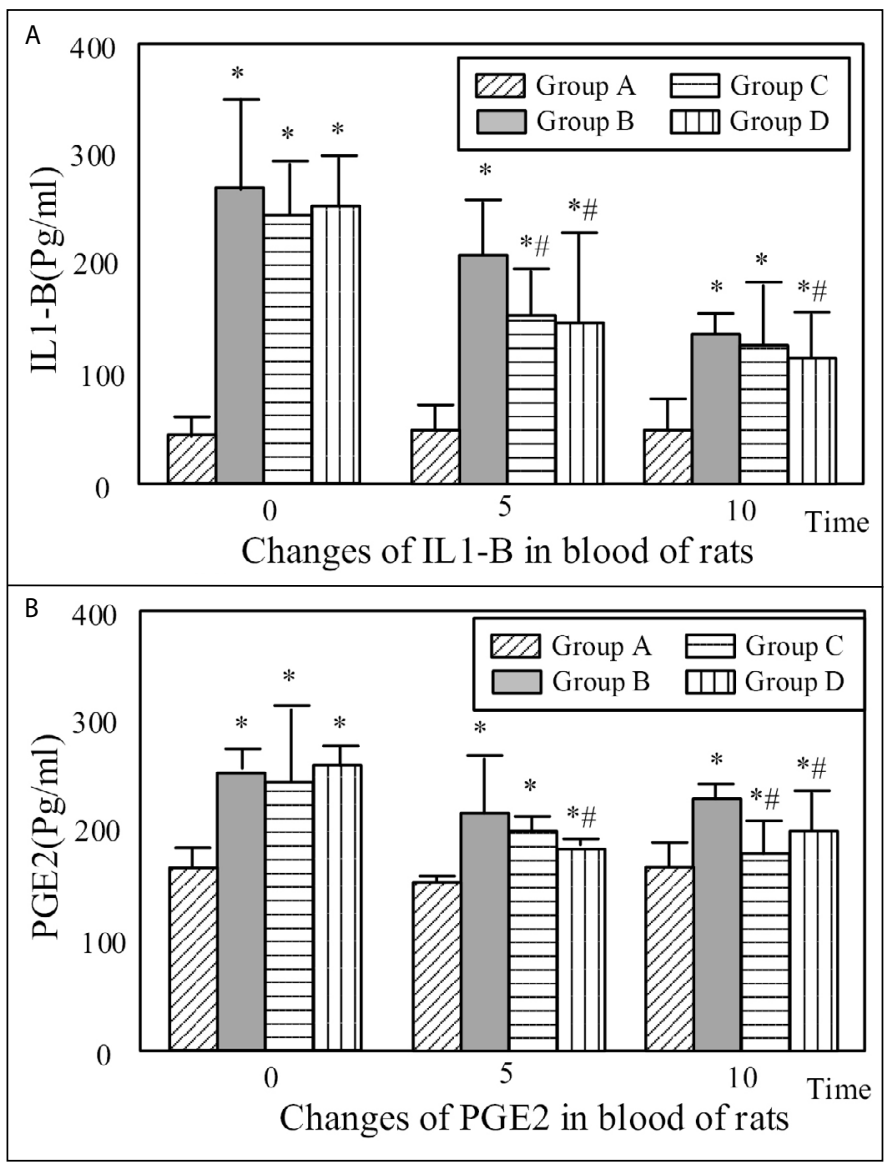

Figure 1. Results of rat blood samples.

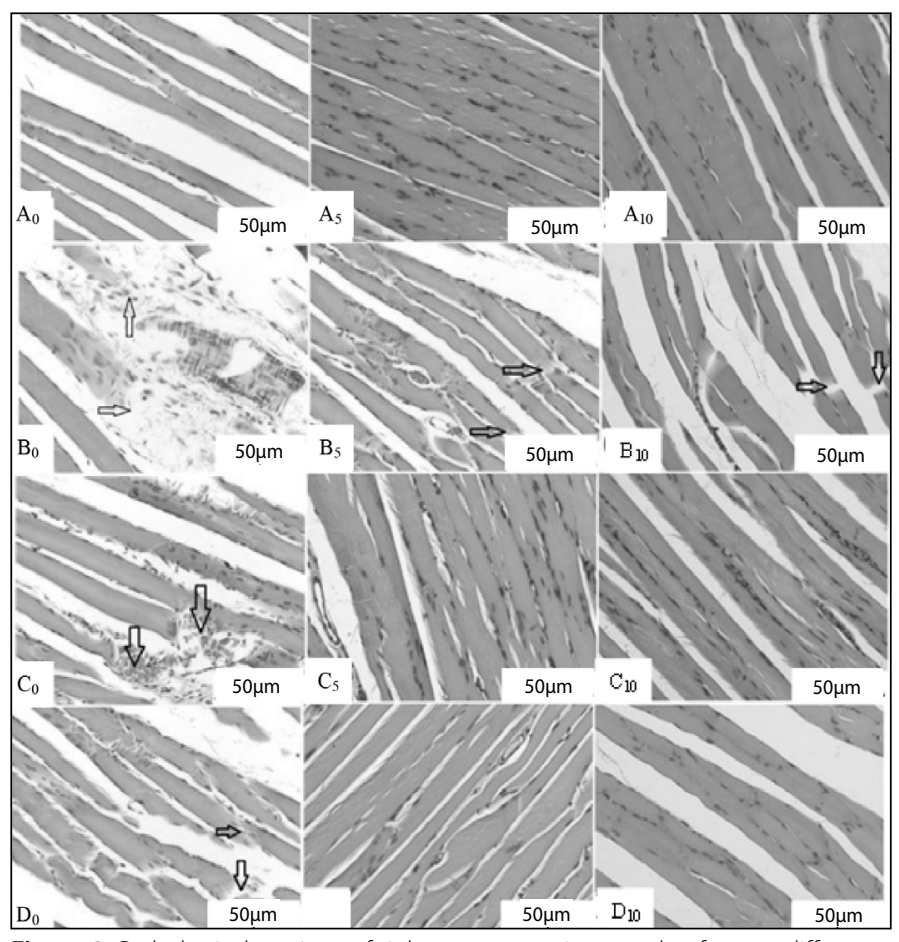

Figure 2. Pathological sections of right gastrocnemius muscle of rats at different.

seen in the tissue sections of rats in groups B, C and d after treatment, while the muscle tissues of rats in group $\mathrm{A}$ are arranged orderly without damage, which indicates that the soft tissue injury model in this study is successful. After five and ten times of treatment, we can see that the muscle tissue arrangement of group $C$ and $D$ is more orderly than that before treatment, and the muscle bundle rupture is also significantly improved. However, the muscle sections of group B still had obvious edema and fracture phenomenon, which indicated that drug intervention could significantly promote the recovery of local injured soft tissue. However, there was no significant difference in muscle tissue recovery between group C and Group D.

Figure 3 shows the levels of ALT and BUN in the blood of rats after 10 times of treatment, in which "* indicates that compared with other groups, $P<0.05$. Figure 3 (a) shows the content of ALT in blood, which is an important indicator for the diagnosis of viral hepatitis and toxic hepatitis. Under normal circumstances, the content of ALT in blood is $0-40 \mathrm{u} / \mathrm{L}$. After ten times of medication, the serum ALT level of Chinese medicine gel was significantly lower than that of the other three groups, and the difference was statistically significant ( $P$ $<0.05)$. There was no significant difference between the other three groups $(P>0.05)$. Figure $3(b)$ shows the blood bun content, which is an important indicator of renal function and the main end product of protein metabolism. The images showed that there was no significant difference in bun content among all rats $(P>0.05)$. The contents of ALT and BUN in the serum of all rats were at normal level, indicating that Chinese medicine gels and tincture did not affect the function of liver and kidney.

The liver and kidney tissues of rats in each group were sectioned, and the image after 400 times magnification was shown in Figure 4. The "L" in the figure represents liver tissue and "K" represents kidney tissue. It can be seen from the figure that there are balloon like changes in kidney cells of rats in group B, which may be due to the pathological changes of liver induced by local inflammatory reaction after long-term untreated soft tissue injury. A. There were no obvious changes in the tissue sections of the rats in groups $C$ and D, which proved that the two drugs had good therapeutic effects on soft tissue injury. 


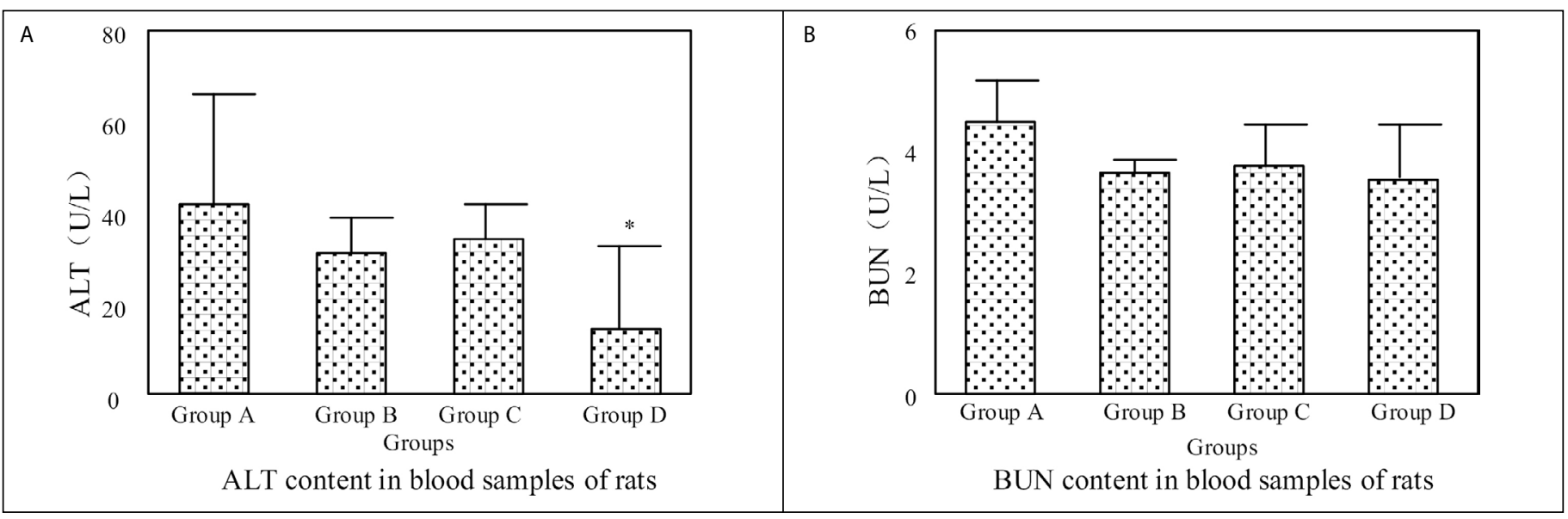

Figure 3. ALT and BUN contents in blood samples of rats after the tenth treatment.

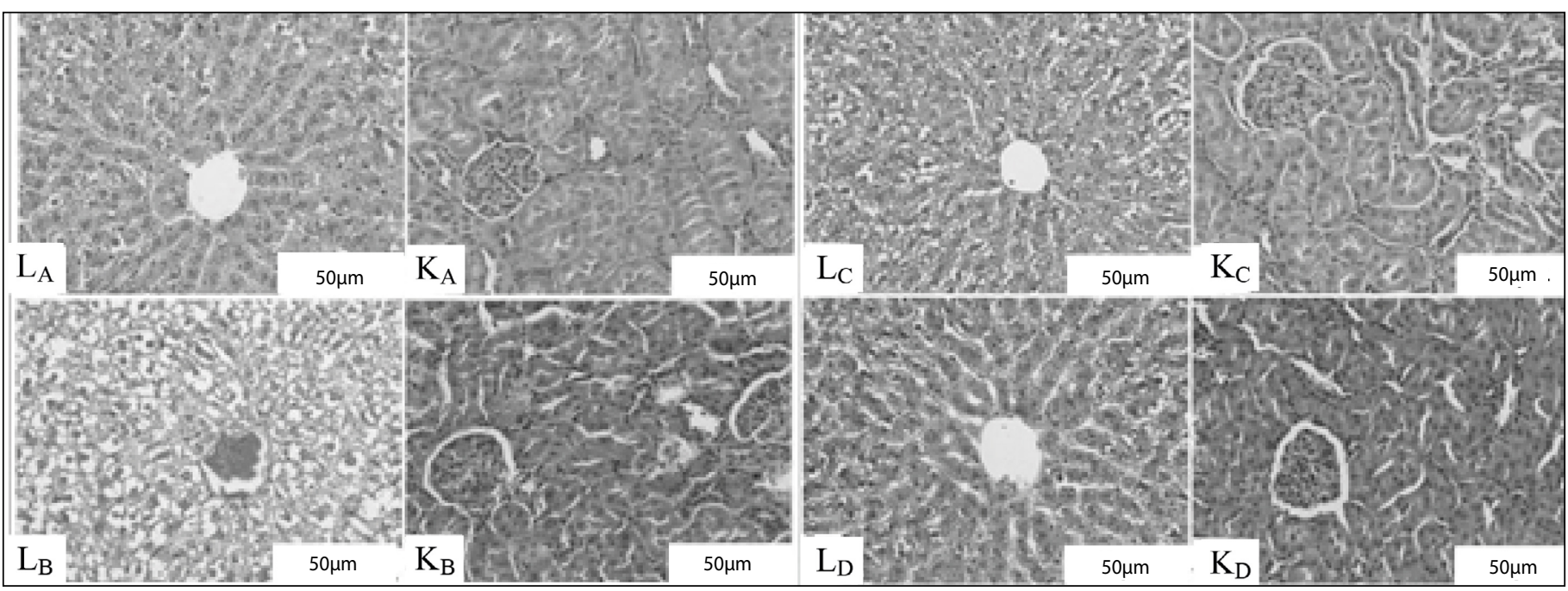

Figure 4. Pathological sections of liver and kidney in rats after the tenth treatment.

\section{CONCLUSION}

Traditional Chinese medicine gel is a safe, effective, convenient, clean and hygienic new dosage form for external use. It has been applied more and more in clinic. It has a very significant effect in the treatment of sports injury, fracture or tendon injury. It can promote blood circulation and remove blood stasis, reduce inflammation and relieve pain. The purpose of this study is to analyze the effect and mechanism of traditional Chinese medicine gel on sports injury. Soft tissue blunt impact model was used to establish soft tissue injury model in adult rats. The detection indexes of soft tissue recovery effect included inflammatory index IL-1 $\beta$, PGE2 and soft tissue examination of injury site, while the examination of drug toxicity included serum indexes ALT and bun. The results showed that there was no significant difference between Chinese medicine gel and traditional tincture in the treatment of soft tissue injury $(P>0.05)$, and there was no obvious toxic side effects on liver and kidney organs. The mechanism of action of the two drugs in the treatment of soft tissue injury is to reduce the levels of $I L-1 \beta$ and PGE2 in the blood, and improve the level of local soft tissue recovery. The effect of gel preparation on the level of IL-1 and PGE2 is higher than that of traditional tincture, and the effect of treating soft tissue injury is slightly better than tincture. These findings will have some guiding significance for the treatment of soft tissue injury caused by sports. Further studies should be made on the actual effects and problems of Chinese medicine gel in the treatment of human soft tissue injury.

\section{ACKNOWLEDGEMENTS}

The study was supported by the Fundamental Research Funds for the Central University (No: 2020 Self research - Sports 009).

All authors declare no potential conflict of interest related to this article

AUTHORS' CONTRIBUTIONS: The author has completed the writing of the article or the critical review of its knowledge content. This paper can be used as the final draft of the manuscript. Every author has made an important contribution to this manuscript. Meiling Miao: writing and execution. Li Chen: data analysis.

\section{REFERENCES}

1. Luokkala T, Temperley D, Basu S, Karjalainen TV, Watts AC. Analysis of magnetic resonance imaging-confirmed soft tissue injury pattern in simple elbow dislocations. Journal of Shoulder and Elbow Surgery. 2019; 28(2):341-348.

2. Yang F, Tan MS, Yi P, Tang XS, Hao QY, QiYN. Clinical study on spinal cord decompression combined with traditional Chinese medicine for the treatment of cervical spondylotic myelopathy. Zhongguo Gu Shang. 2018;25;31(1):30-36.

3. Wu XK, Stener-Victorin E, Kuang HY, Ma HL, Gao JS, Xie LZ, et al. Effect of Acupuncture and Clomiphene in Chinese Women With Polycystic Ovary Syndrome: A Randomized Clinical Trial. JAMA The Journal of the American Medical Association. 2017; 317(24):2502-2514.

4. Sh Zhang CS, Yang AW, Zhang AL, May BH, Xue CC. Sham Control Methods Used in Ear-Acupuncture/Ear-Acupressure Randomized Controlled Trials: A Systematic Review. Deutsche Ztschrift Für
Akupunktur. 2017; 60(1):32-33

5. Unalmis Erdogan S, Yanikkerem E, Goker A. Effects of low back massage on perceived birth pain and satisfaction. Complement Ther Clin Pract. 2017;28:169-175

6. Wang M, Chen L, Liu D, Chen H, Tang DD, Zhao YY. Metabolomics highlights pharmacological bioactivity and biochemical mechanism of traditional Chinese medicine. Chem Biol Interact. 2017; 273:133-141.

7. Zhao HD, Xie HJ, Li J, Ren CP, Chen YX. Research Progress on Reversing Multidrug Resistance in Tumors by Using Chinese Medicine. Chin J Integr Med. 2018;24(6):474-480.

8. Zhang S, Tang D, Zang W, Yin G, Dai J, Sun YU, et al. Synergistic Inhibitory Effect of Traditional Chinese Medicine Astragaloside IV and Curcumin on Tumor Growth and Angiogenesis in an Orthotopic Nude-Mouse Model of Human Hepatocellular Carcinoma. Anticancer Res. 2017;37(2):465-473. 